\title{
Socio-economic and Environmental Assets Sustainability by Agroforestry Systems: A Review
}

\author{
Vikram Singh', Vishal Johar ${ }^{1 *}$, Rupender Kumar $^{2}$ and Mukesh Chaudhary ${ }^{2}$ \\ ${ }^{1}$ Department of Horticulture, School of Agriculture, Lovely Professional University, Phagwara, India \\ ${ }^{2}$ Department of Agricultural Economics and Extension, School of Agriculture, Lovely Professional University, Phagwara, India \\ *Correspondence author: vishal.26021@lpu.co.in (ORCID ID: 0000-0002-5639-1771)
}

Paper No. 940

Received: 20-09-2021

Revised: 26-11-2021

Accepted: 16-12-2021

\begin{abstract}
Agroforestry has a long history in ancient times, and it has been widespread everywhere until now. Agroforestry systems with native trees as well as introduced trees provide an exciting illustration in which sustainability, regulatory, habitat, provisional, and other environment pairs are at the same time exploited. In the present review study, the potential of the agroforestry system to optimize different socioeconomic returns like food, fuelwood, fodder, fiber, timber, non-timber forest products, and additional income, etc. Potential of agroforestry system in the farm of environment services protect soil erosion, bioenergy, affects to carbon fixing, diversify agricultural landscapes with trees, sustainable land management practice, control of pests by their natural enemies and habitat of biological diversity in the world. The review indicates that the nation's cultivators should be awake and aware of agroforestry system possibilities and competence, and these growers should contribute in developing the cultivation of agroforestry system viable as economically returns as well as environmentally returns for world farmers. To increase tree cover areas of the world out of the total geographical areas, the agroforestry system has the competence to provide a faster rate of tree farms increment according to forest policies for the sustainable livelihood of the farmers.
\end{abstract}

\section{HIGHLIGHTS}

( Agroforestry systems impact positively on ecology and environment.

( Agroforestry systems have a reversible relationship with livelihood and biodiversity in multifunctional landscapes.

Keywords: Agroforestry, environment, socio-economic, biodiversity, and livelihood

The National Agroforestry Policy (2014) defines agroforestry as a combination of land-use systems which combines trees and shrubs on farmlands and rural landscapes with or without livestock to enhance productivity, profitability, diversity, and ecosystem sustainability. In India, forestry and agroforestry land are about 69.79 (FSI, 2013) and 25 Mha (Dhanya et al. 2013) respectively, out of the total existing geographical area of 305.60 Mha. Agroforestry helps in Carbon stocking is about 532.5 Mt. Further, the scattered trees are accessible in a farm field and field bunds. Agroforestry helps to secure $C$ stock availability is half of the $C$ stock present in the forests, and recent Studies show that area under agroforestry will increase significantly in the future in India(NRCAF, 2006). There were many studies that found that the agroforestry system is an awe-inspiring technique of carbon sequestration, and the efficient role was storing carbon biomass above ground (Mukherjee et al. 2015) and also for storing the carbon biomass bin below the ground

\footnotetext{
How to cite this article: Singh, V., Johar, V., Kumar, R. and Chaudhary M. 2021. Socio-economic and Environmental Assets Sustainability by Agroforestry Systems: A Review. Int. J. Ag. Env. Biotech., 14(04): 521533.
}

Source of Support: None; Conflict of Interest: None 
(Nair et al. 2010). Agroforestry vast prospective in India, the adoption rates are slow because present challenges lack the benefits of agroforestry like lack of market infrastructure, shortage of superior planting material, wood transportation, processing, insufficient research, cumbersome and frustrating legislation in respect of tree (Sharma et al. 2017). The agroforestry system was the major source of reducing the pressure on the forests by increasing the tree cover in the landscapes. Higher potential to increase environmentally and economically returns to the local society for major distribution in agriculture to get food, fodder, timber, fuelwood, and fiber for the developing socioeconomically status (Bijalwan et al. 2011).

Agroforestry is a system that combines old knowledge with the modern science of the country and the ideas of the small thinking's and produces higher possibilities of economic returns of the goods. Climate change has a big problem, and the solution is that increase the forest and tree cover by adopting agroforestry system with increasing resilience of the cultivation system by the sole crop adopters of the farmers (Dhyani, 2014). Agroforestry was meeting the demands of the plywood, good quality of raw material for paper and pulp, small and bigger house making timber, protein-rich green fodder for livestock, fuelwood to daily consumption of the local peoples and also for the improving the environment by reduction of the pollution (NRCAF. 2013). In maintaining the uniqueness and sustainability of agroforestry system, management practices are played a major task. Management of the agroforestry system is complicated because of the different mixed species of the affected agronomic; physiological and phonological demands are variable compared to the sole crop agriculture system (Manna et al. 2018). The traditional agroforestry practices are in perform by the local people since ancient times with various multipurpose trees are deliberately used by the farmers on their farm field and maintaining their density, frequency, and largely varied as per the local and climatic factors (Bijalwan et al. 2014). Traditionally, farmers allocate Acacia nilotica, Butea monosperma and Terminalia arjuna, etc., which are naturally grown in the bunds as sporadically spacing in India. Acacia nilotica was very prosperous to the farmers because it has the potential to fix atmospheric nitrogen and easily widespread in the field without any problems. Similarly, a large plantation of Azadirachta indica helps to reduce deforestation, improves soil condition, remove desertification lands, and rehabilitation of global environmental temperature (Jhariya et al. 2013). The multi-class configuration of agroforestry system of northeast India was informed by a few workers (Bijalwan et al. 2014). The development and application of agroforestry techniques that are developed by local adopters are accepted techniques based on our knowledge, awareness, intelligence, risk orientation, thinking's and prediction of maximum output (Erakhrumen et al. 2010). A local study says that the maximum quantity of fuelwood or firewood comes from the woodlots which are situated outside of the forest like agroforestry farms, as well as traditional sporadic regeneration of the tree covers in the boundary of the field (Horst and Hovorka, 2019).

Agroforestry system is mainly predominant in the arid and semi-arid regions of the country and irregular forms of the native trees like Leauceana spp., Prosopis spp., Acacia spp., and Ficus spp. in the form of silvopasture system practiced by the local cultivators prominently in India (Viswanath et al. 2018). Nitrogen-fixing trees adoption by the local farmers with native species in the agroforestry system showed significant action for increasing the net income, opportunity for the employment of the local people, reduction of environmental pollution, and health of the soil by positive tree crop interaction (Jahriya et al. 2016).

\section{METHODOLOGY}

This study processed by the review of the last 20 years types of research published in the field of agroforestry were analyzed and read carefully by the author's collected helpful information about the significance of the agroforestry system. These papers helped to gain the other important knowledge about the agroforestry systems, and all papers had been listed in the reference parts for the authentication of the study. This review paper had been effective impact where agroforestry system was adopted by the communities and also increased the awareness of the significance of this system spread all the world. This review paper setup the positive impacts, importance, benefits, suggestions, future scope 
and recommendation of the adopting agroforestry model for the improvement of the socioeconomic and environmental assets sustainability.

\section{Scope and Potential of Agroforestry}

Agroforestry helps the study for conservation of ecosystem, biodiversity, production of the goods, sequestering carbon, fertility of the soil of degraded areas, generate income and socioeconomically profitable because of the direct and indirect benefits of this system significantly affect (Pandey 2011). Agroforestry system focused on improving or developing sustainability of socio-economic return and also a sustainable form of fulfilling the landscape by the plantation of native tree species (Kittur and Bargali 2013). Agroforestry were given sustainable livelihoods of small and which depend on this system like subsistence farmers can generate income quickly, helps to the sequestration of the carbon, reduction of flexible change of the environment through the agroforestry techniques (Buchman 2010). The role of agroforestry was very bigger because the tree covers an important natural source for the cleaning environment and the combination of the agricultural crops helps to make more fertile soil, benefits to the plants and microorganisms of the surrounding areas. In the world, more unpredictable changes of the climate like drier, warmer, colder are reduced by the adoption of the agroforestry plantation, which reduces environmental pollution (Mccabe 2013). The scope and potential of agroforestry are enviable and permit most annual crops to grow well with tree species in the same unit of field. According to a study, agroforestry has many potentials like soil fertility, soil conservation, enhanced overall (biomass) productivity, improvement, nutrient cycling, bio drainage, bio-energy, biofuel, microclimate improvement, and carbon sequestration, etc. (Fanish and Priya 2013). The adoption of agroforestry system farmers can increase the agriculture diversify by the without extra used lands and helps to the soil improvement, reduces soil erosion, carbon emission, microclimate improves, ecosystem changes and improvised the equity of the genders which practicing agroforestry (Rao, 2017).

\section{Tree crop interaction in Agroforestry}

In the agroforestry system, the interaction between tree and crop depends on the type of the model, species selection, composition of varieties, and affect the nature of family affected positively by the mutualism, negatively by allelopathy, and neutral competition. In tree, crop interaction is usually a result of the competition of the different forms of the component, and also, a single form of a variable affects the system (Nair 1993). In the Agroforestry system were very important to study of the interaction because positive interaction helps to increase productivity and negative decreases productivity so that we can use the appropriate model for the strengthening of the productivity of the land. In agroforestry, mainly positive interactions are increased productivity, soil conservation improved soil fertility, nutrient cycling, and also environmental pressure improved and major negative effect of interaction is competition for light, nutrients, space, and moisture, which slowly reduces the yield. Ecological sustainability and achievement of tree crop combination depend on the relationship and complementarily between positive and negative interactions (Sarvanan et al. 2013). Treecrop interface studies were carried at NRCAF, Jhansi in neem plantation of 8-year-old age to calculate growth concept and output of neem and below canopy crop black gram (Phaseolus mungo). In this interface, wood volume and fruit yield of neem trees gave higher economic returns, which fulfill output of crop yield under the tree cover decreased. Neem trees with nitrogen, phosphorous, potassium, and calcium potential return are 2.25, 32, and $131 \mathrm{~kg}$ per ha, respectively (Pandey et al. 2012). Agroforestry has the possibility to deliver food security, poverty reduction, environment security, soil conservation, and carbon sequestration are vastly important. Old-style farming and their supervision, such as the agro-forestry system, provide opportunities to enhance incomes through synchronized production of food, fodder, and firewood and reducemate change effect (Tiwari et al. 2017)..

\section{Soil health improves by Agroforestry}

Agroforestry systems were land management systems because the tree roots improved the quality of water absorption, increased the beneficial microorganism, which improved the richness of soil nutrients (Murthy et al. 2013). Different land-use systems or agroforestry systems were discovered 
at CRIDA, Hyderabad, India as Physico-chemical properties of soil organic carbon and soil $\mathrm{pH}$ were significantly increasing (Sharma et al. 2019). Tropical agroforestry system integration of trees and crops in the same unit of land nitrogen fixer trees are capable of fixing the nitrogen from the atmosphere in the field, and non-nitrogen fixes trees also improve the field by the organic matter by a litter of tree, recycles nutrients and enhances the soil chemical and physical properties (Jose 2010). In the central Punjab, India, a study revealed that a combination of poplar and wheat agroforestry system in the winter season and green gram in the summer season increases the average soil organic carbon as 0.36 percent in the sole crop in agriculture soil and 0.66 percent increase the agroforestry soil and same increment with increases tree age (Gupta et al. 2013). In the agroforestry field, various multipurpose tree species significantly affect cultivation in the northeastern Himalayan region in India and found that all soil hydro-physical characteristics were significantly enhanced by the trees (Saha et al. 2010).

Agroforestry systems were proven to be gifted for the environment to improve polluted land, decrease soil salinization, and acidification (Murthy et al. 2013). Agroforestry systems help in phyto and dendro remediation, rehabilitation of degraded landscapes to improve soil properties and control invasion of the weeds in the open field and provide the situation to natives by short-rotation woody crops that can remediate polluted soil and groundwater (Rockwood et al. 2014). Farmers of the Palani Hills in southern India were improved fallows by using invasive leguminous trees (Acacia sp.), which were controlling 'negative' plant invasions into productive agroforestry systems(Tasssin et al. 2012). Agroforestry systems were usually produce more biomass which converted into the litter with the help of various microorganisms, increases the organic carbon of soil (Aldeen et al. 2013), rhizosphere effects conserve the different types of nutrients with increasing the fertility of land (Saha et al. 2010), water absorption quality and quantity of the soil increase, increase the income of native people by the agroforestry practices in the same unit of land (Anderson et al. 2015). A study by (Raj et al. 2014) reported that agroforestry practices increase the quantity of microorganism in the soil, which improves microbiological action of land, contributes the recycling the fertility of agroforestry lands, improves the environmental condition of the field and sustainability of the socio-economic condition of the cultivators of the native regions.

\section{Economic and social benefits of agroforestry}

A significant social benefit through agroforestry affects marginal and small landholdings of the farmers because of the limitation of the land and increase the productivity by the agroforestry system in the same piece of field. The enrollment of the women and children in the agroforestry system more benefitted because of the more care of the cultivation with the head of the family found in the Rajasthan, Uttar Pradesh, and Gujarat in India, where agroforestry was introduced found that more benefits to women conditions (Bose 2015). The socioeconomic conditions of agroforestry farmers and non-agroforestry farmers comparison in Bangladesh reported that farmers adopting agroforestry are better off than those adopting non-agroforestry, both socially and economically (Chakraborty et al. 2015)and similarly,reported ineastern Uttar Pradesh (Singh and Ramchandra 2019). Similarly, a study in the Nilgiris Biosphere Reserve, Kerala find that those farmers are engaged with the cultivation of any kind of agroforestry system practices received significant returns as like food, security of livelihood, additional income, and reduced climatic pollution (Kumar 2010). The natural forest cover of India is declining, and timber productivity in forests has been assigned low in India. Agroforestry offers tested techniques to sustain the forest goods production and integrity of natural forests through the adoption of fast-growing foreign species are play a significant role on agricultural lands. Adoption of agroforestry was essential to make successfully integrate the exotic tree species under various farm/agroforestry systems to increase productivity, generate income, reducing the gap between forest products (Bangarwa and Sirohi 2018).

The socio-economic benefits through agroforestry are very important in at last determined by farmers as a possible alternative practice to conventional 'modern' agricultural practices (Saha et al. 2010). Agroforestry systems are reserves of a variety of timber species which are not give earlier benefits, which means growth time is higher. After two decades, these timber species give better 
results in comparison to initial stages (Dagar et al. 2014). The productivity of the land increases when soil properties improve by agroforestry than certainly improves the earning potential of the farmer. A study gives results the combination of Psidium spp. and local agriculture crop adopted based agroforestry system total cost and benefits of the net returns find approximately three times more than similar agriculture sole crop system in the study area in India (Murthy et al. 2013). Agriculture compared with adoption of agroforestry system were generally gives more quickly benefits because of the income generated directly with the agriculture sole crop system every year (Rodríguez et al. 2011). Still, more studies showed that after the rotation of tree species increased the profitability of different agroforestry system like silvopastoral (Benavides et al. 2013) and silvo-arable systems compared to agricultural monoculture systems. Eucalyptus-based agroforestry system is more popular with the combination of the paddy, wheat and other higher rate of irrigation crops in the sporadic form in the boundary and bund plantation in the irrigated field. Eucalyptus hybrid is the most valuable spp. Because fast-growing, coppices well, capable of over-topping weeds, fire hardy, browse resistant and adapt a wide range of edapho-climatic conditions. Eucalyptus plantation can reduce pressure on natural forest, supply a good quantity of pulp and fire-wood, timber, maintain biodiversity and litter decomposition improves soil water holding capacity, porosity, texture, nutrient, and yield improvement. Eucalyptus boundariesbased agroforestry plantations produce a short rotation harvestable tree crop within four to six years (Jhariya et al. 2016).

The socioeconomic status and livelihood support through predominant traditional agroforestry systems were agri-silviculture, agri-horticulture, and Agri-Horti-silviculture in Garhwal Himalaya, India. The adult literacy rate was $43 \%$ in marginal, $54 \%$ in miniature, and $73 \%$ in medium-large landholding families, while the child education rate was 86,98 , and $100 \%$, respectively. The livestock was kept by 37 to $56 \%$ of families, and each family had 2 to 4 mulch animals, and only 8 to $18 \%$ of families kept oxen. The average fuelwood consumption was 84.41 to $538.45 \mathrm{~kg} /$ day/village, which is supplemented by existing agroforestry up to 156.75 to $701.01 \mathrm{~kg} /$ day/village considerable extent. The utilization of tree fodder in summer and winter was 305.02 to 1015.17 and 659.53 to $2015.52 \mathrm{~kg} /$ day/village, respectively, which is supplemented by traditional agroforestry trees. Agroforestry practice is reported to be supportive and sustainable practice in this area and plays a significant role in the different facets of the household for their sustenance (Bijalwan et al. 2011). Small landholdings farmers take more benefits as well as improve our livelihood by the adoption of agroforestry systems and grows the same field like medicinal plants, fruit trees, nuts, fodder when non-availability of the grass, fuelwood, timber, additional diversified income (World Agroforestry Centre 2010).

Agroforestry systems reported in the studied area increase their income, easy availability of firewood, timber on the farmland to farmers, conservation of natural forest, and socio-economic livelihood of rural population (World Agro-forestry Centre 2010).

\section{Agroforestry to check atmospheric $\mathrm{CO}_{2}$}

Due increased level of $\mathrm{CO}_{2}$ in the world affects the climatic change because of the rising temperature continuously, increasing the pollution due to carbon enhancement, so these problems diminished through the tree plantation in the bigger size and lands are limited. Agroforestry system is a perfect solution for the decreasing level of $\mathrm{O}_{2}$ because agroforestry provides tree plantation in the agricultural land and landscapes where the large size of the plantation should be done and mitigate the greenhouse gases very quickly through the agroforestry plantation (Nair et al. 2010). In India average carbon storage potential by the agroforestry system, which facilitates the tree plantation area, increased. The country accounted for 25-ton carbon per hectare, and this competence depends on the growth and cultivation of the tree cover in the agroforestry system (Pandey 2011). Agroforestry systems store approximately 280 metric tons of carbon in India, but this carbon amount is distributed and diversified by the different climatic zone according to the characteristic of the plantation (FSI, 2013). Indo-Gangetic Plains were the adoption of the agroforestry system is higher due to the climatic condition and find that approx. 70 percent of soil carbon in the depth of the upper side of half a meter of the soil profile, where carbon storage was about 
8 to 15-ton carbon per hectare, but in agricultural soils, $1 \mathrm{~m}$ soil depth contain 12 to $23 \mathrm{tC} /$ ha of organic carbon (Singh and Pandey 2011). Agroforestry is a good option for climate change mitigation through carbon sequestration plantation in the soil depth. It increases biomass production as an alternate source of the decrease the dependence in the natural forest products placed by the produce agroforestry in the agriculture fields generate farmer's income as soon as possible (Sudha et al. 2013). Agroforestry plantation activity sequestering carbon dioxide $\left(\mathrm{CO}_{2}\right)$ into the soil, secure cropland, windbreak, protect biodiversity, provides food and feed to human and livestock, wood for fuel, pollen for honey bees, and timber for housing construction. Agroforestry is a more smart land use practice for the farming society worldwide instead of cropland and forestland management systems because this practice is always a win-win situation for the farming society as well as for environmental sustainability (Abbas et al. 2017).

\section{Biomass and carbon storage through Agroforestry}

In India, agroforestry systems can sequestration carbon per year estimated between $0.5-20$ and 0.01 to $0.50 \mathrm{mg}$. carbon per hectare for the combination of tree cover and crop component, respectively, which helps to improve better quality of the yield at the same land. Generally, carbon sequestration depends on the locality, species characteristics, adoption of a combination of the tree crop selection, species selection, quality of the production, and which type of practices were previously used in the many years in the agroforestry system (Dhyani et al. 2016). The biomass and carbon storage were evaluated in an artificially established agroforestry experiment on Albizia procera and Dalbergia sissoo under irrigated conditions and Emblica officinalis and Hardwickia binata under rainfed conditions. A. procera accumulated maximum biomass $120.42 \mathrm{t} / \mathrm{ha}$ at 11-year-old followed by $D$. sissoo which accumulated $84.75 \mathrm{t} /$ per ha biomass at 17-year-oldirrigated conditions. Similarly, biomass accumulation in $E$. officinalis accumulated $14.99 \mathrm{t} / \mathrm{ha}$ at 15-year-old and $H$. binata accumulated $101.34 \mathrm{t} / \mathrm{ha}$ biomass at 20-year-old. A. procera fast-growing tree had maximum $10.95 \mathrm{t} / \mathrm{ha} / \mathrm{yr}$. followed by D. sissoo (4.99 t/ha/yr), H. binata (5.10 t/ha/yr) and E. officinalis
(1.03 t/ha/yr), respectively. The carbon storage in $A$. procera was maximum (57.03 tC/ha) followed by $D$. sissoo (36.62 tC/ha), E. officinalis (7.12 tC/ha) and $H$. binnata (46.13 tC/ha.) (Ramnewaj et al. 2016).

The cultivation of home gardens was mostly indirect but, in the study, found that any practice which contributes to higher productivity will indirectly lead to higher Carbon sequestration (Subba et al. 2017).

\section{Recover fossil fuels and source of fuelwood through Agroforestry}

The agroforestry systems were the potential to reduce dependence on fossil fuel consumption because the plantation of trees in the local field with agricultural crop generally fulfill the demand and produce more quantity of the fuelwood, which acts as significantly reduces the reliance on fossil fuels of the people (Smith 2010). A study reported that in Bangladesh, the demand for fuelwood is generally fulfilled by the traditional agroforestry system cultivated by the growers, which gives more fuelwood and reduction of the house expenditure on the traditional use of the fossil fuels at the daily use of the livelihood (Chakraborty et al. 2015). A study reported that in western Uttar Pradesh, fuelwood was more than $50 \%$ of the farmer's major driving source by adopting agroforestry system, which reduced the dependence of the other conventional fuel followed by additional income $25 \%$ of farmers adopted the agroforestry model (Dwivedi et al. 2010). Similarly, agroforestry significantly reduced the dependence of communities on nearby forests for fuelwood and reduced the consumption of any other kind of traditional fossil fuels for cooking of the food and generating energy which improves by the coppice system for the small wood production at a larger scale by trimming of the branches. Agroforestry was a sustainable land-use system in ancient times because this system fulfills the requirement of food and fuel along with improving the environment by a different type of combination of the tree at the same place of the field with agriculture crop (CFA, 2010).

The average daily fuelwood consumption in different villages of Chamoli districts of Garhwal Himalayas during summer per village is $83.41 \mathrm{~kg} /$ day to $535.40 \mathrm{~kg} /$ day and in winter $150.70 \mathrm{~kg} /$ day to $757.05 \mathrm{~kg} /$ day and the utilization of fodder tree 
$301.05 \mathrm{~kg} /$ day to $1009.15 \mathrm{~kg} /$ day in the summer and in the winter $650.50 \mathrm{~kg} /$ day to $2011.50 \mathrm{~kg} /$ day which is supplemented by traditional agroforestry trees (Rawat et al. 2016).

\section{Agroforestry enhanced air quality}

Agroforestry contributes to reduced environmental pollution by landscape plantation with higher oxygen producer plants and conserves the biodiversity by expanding area of natural habitats in the limited area like agriculture field, in between existing reserves and landscape and creating corridors, where the landscapes was available from past years (Nath et al. 2016). Agroforestry components like windbreaks and shelter-belts promote air quality and reduce pollution. Windbreaks and shelter-belts also reduce wind chills, erosion, and particulate matter in the air, remove atmospheric carbon dioxide and improve oxygen circulation, provide additional habitats for wildlife, protect crops, reduce wind velocity, reduce noise pollution and livestock odor (Tyndall and Colletti 2011). Agroforestry more tree vegetative parts have been showing the reduction of the non-point source of the pollution which arises by the sole crop of agriculture plants diminish by the agroforestry plantation in the agriculture field of the native areas (Anderson et al. 2015). Agroforestry plantation has capable of filtering airstreams of particulates, removing the odor causing aerosols, and provision of clean water but agriculture has numerous effects on water systems, pesticide pollution, changing water chemistry through eutrophication, changes the food web, and increasing sediment load from erosion (Moss 2018).

\section{Agroforestry maintain microclimate}

Tea crop under agroforestry plantation of alley cropping system revealed that the temperature of the soil, as well as environmental temperature, were lower down 2 to $5{ }^{\circ} \mathrm{C}$ compared to the non-shade condition of the agriculture crop in an open field and humidity also affects with increase about 5 to 10 percent inside the tea-based agroforestry combination in the shaded areas. The shade of the different tree crop appeared as beneficial for tea crop yield productions well as shelterbelt and windbreak are also makes protecting function extensively used for microclimate change
(Mukherjee et al. 2015). Agroforestry systems were Prosopis-based silvopastoral system of eight-year plantation have the microbial biomass carbon in the soils of was significantly higher than in soils under sole plantation of trees and control systems. This system proved more effective in reducing soil $\mathrm{pH}$, improvement in soil physical properties, increasing organic carbon, displacing $\mathrm{Na}+$ from the exchange complex and available $\mathrm{N}$, $\mathrm{P}$, and $\mathrm{K}$. than in the silviculture system. Due to biomass production and improvement in soil health silvopastoral agroforestry system could be adopted for sustainable retrieval of highly alkali soil (Singh and Dhayani 2014).

Agroforestry systems cover different representations in various regions of the world, which plays a fortunate role in fighting the bad impact of climate change by increasing tree-crop modification that's improve more carbon storage or carbon sequestration volume in comparison to the sole cultivation of agricultural crops (Toppo and Raj 2018).

\section{Agroforestry develops natural resources}

Agroforestry techniques were very old practices from the ancient era because the demand for food and fuel was very higher, and this system provides in the same land of agriculture, further now a day's its technically developed, modified, make more accessible and scientific work promote this technique in many parts of the world adopted faster rate. Agroforestry studies have shown that many cultural, socioeconomic, and political factorsere reliable for components integration into and sustenance of agroforestry (Erakhrumen 2012). In Nigeria, most of the children and women generated our income through the sold out of the fuelwood produced by the agroforestry system easily for our livelihood, so that the demand for fuelwood fulfills by the agroforestry system not reliance on the natural forest or woodlots for the fuelwood consumption in southern parts of Nigeria (Ogunsanwo and Erakhrumen 2010). Agroforestry studied recommends that combination of other components with fuelwood plantation have renewable natural resources production methods as an agroforestry scheme. Still, sustenance of these schemes was essential to awake farmers and campaign to higher authorities to give information 
related not to use particular or traditional cultivation of sole agriculture components replaced by the agroforestry practices (Erakhrumen 2012).

\section{Agroforestry as Artistic and Traditions}

Agroforestry systems were used by the farmers as an art and traditional knowledge of system because it's very complex in comparison to the sole cropping system, and it's strengthened the socioeconomic and environmental reformation significantly since prehistoric times. A study reported that government helps to tree plantation and agroforestry plantation scientifically promoted because of the output from the tree-related yield was tremendous growth of the livelihood of the village peoples, income source by sold-out timber and non-timber products and sustainable employment produced by the tree plantation system-related availability of fodder, fruit, wood, and fuel (Basu 2014). Conventional agroforestry system like home gardens was an art for a long time because it provides basic needs as well as aesthetic value and ornamental scene of the areas so that increasing value of nature should maintain the orchard, kitchen garden, pasture lands, tree lots, and home gardens where an area of more landscapes (McAdam and Mosquera 2019).

As per study (Franco et al. 2013), it was reported that there is a need to believe the morals of society places as ornaments aspects such as the beauty of the nature and improve the scenario of the landscapes, which location, after plantation decrease the environment pressure and remove the pollution of harmful gases, presented the landscapes and surroundings of the locality. In temperate areas have already presented big size of forest and woodlots by the natural climatic conditions, so that need of the demands of tree product fulfill by these woodlots. In contrast, in these areas, less or few noticed the traditional agroforestry plantation but even with long histories of woodland and orchard grazing, parklands, alpine wooded pastures and pannage (McAdam and Mosquera 2019). A study in the western areas of Tripura where old plantation diversity presented in a large size because of the involvement of the women and children to maintain and management by different socio-house groups which believed that the traditional knowledge and awareness by the local belief practices. Participation of these women large size which located in the tribal areas and non-tribal areas of this state worked in agroforestry was compared and found that the last participated more in marketing behavior than the former because of the more involved in production, management, and harvesting source of wood (Jaba et al. 2015).

\section{Agroforestry secure livelihood}

India is well-known for the subsistence of valuable traditional knowledge about tree crop planting. Area less than 2 ha small land holding, farmer cultivated paddy and babool based agroforestry system traditionally and find result indirect benefit of fertility improvement by the fixing of nitrogen from the atmosphere and directly contributed benefit/ cost ratio of 1.5after the rotation period of 10 years in the study area (CFA, 2010). Agroforestry plays an essential role in the world economy by way of tangible and improve an environment by intangible benefits because helps in treated the degraded and increases the productivity of the country. The chief allocation of the land under agroforestry will come from landscapes, fallows, cultivable fallows, pastures, groves, and rehabilitation of degraded soils. Agroforestry focused basic needs of the growers like improving bio-fuels, employment, carbon sequestration, and farm productivity. This will be possible through appropriate research interventions, adequate investment, and suitable extension strategies, along with a forward-looking agroforestry policy (Dhyani et al. 2017).

Grewiaoptiva wonder tree of western Himalaya, locally known as Bhimal, is the most common multipurpose tree of the Garhwal Himalayan region. This tree was abundantly grown as traditional agroforestry along with most of the agricultural crops. The G. optiva + wheat based agroforestry system is a common practice by the local people to supplement the additional benefits from the tree. The G. optiva is rated as a good fodder tree, fiber, fuelwood (Bijalwan et al. 2014). Similarly, according to (Singh and Pandey 2011), the G. optiva is one of the most significant fodder trees of central Himalaya and north-western, which is found spread throughout the Sub- Himalayan tracts (Bijalwan et al. 2014). Similarly, Agroforestry was the traditional land-use system of Kumaun Himalayas local farmer's preferred Grewiaoptiva, Morus alba as fodder species and Dalbergia sissoo, Azadiracta indica 
as timber species. A high level of crop density in the traditional agroforestry system was maintained by regular change of crops in a small field in time and space (Rao et al. 2017). M. dubia is an excellent tree used in agroforestry because of its highly suitable raw material for wood-based industries like paper and plywood industries, high pulp recovery, natural anti-termite properties, and exceptional fiber strength as compared to traditional raw material (Sarvanan 2013). The M. dubia fruit extracts of the tree found to be a helpful hypo-glycaemic agent and antioxidant useful for the treatment of Melia dubia matured leaves are loaded with a higher amount of crude protein, crude lipid, mineral elements, and vitamins which gives excellent fodder for ruminates (Tyndall and Colletti 2011).

Agroforestry systems offer many ecosystem facilities at a low expense with environmental benefits. That is why it is recommended that farmers of the Bhabhar Region of Kumaun Himalaya should prefer agroforestry systems to enhance the socio-economic status of their livelihood (Padalia et al. 2018).

\section{Agroforestry prospect for future strategies}

In a world, both types of agroforestry system like traditional and artificial management of land gives significant benefits and competence of many aspects like providing employment, processing, and value addition of production. According to an approximation, one hectare of the plantation land in timber industries create around 450 man employment, and 30 million ha of land has the potential to generate around 15,000 million mandays of employment. Agroforestry major role play in the future because of its importance of providing livelihood security to humans by fulfilling the supply of food and for the livestock demand of fodder in the same unit of the field at the same time as well as the reformation of the ecosystem and local habitats microclimate improvement possible through this system because country's cultivating geographical area of the world cannot be increased (CAFRI, 2015). Agroforestry is the only alternate plan to fulfill the Indian forest policy, 1988, which aimsto increase the developing forest area to 33 percent in comparison to the present area of less than 25 percent and agroforestry will play a major action for promising in the area of environmental services. The present FSI, 2019 report area under agroforestry in India is estimated as 27.36 million hectares or 9.37 percent out of the total geographical area of the country, representing about could potential to increase the area under agroforestry by the local and government policies to improve tree cover of the country shortly.

Agroforestry is a significant opportunity as a mitigation policy to climate change and rehabilitation of landscape, degraded land, and the conversion of a pure cultivated mono-crop system into agroforestry helps carbon sequestration. It makes land productive in numerous ways and a cropping system (Dasgupta et al. 2016). In India, a government center report said that till 2050 the demand for timber and food production of the country will be increase at double or triple rate of the present consumption rate of the population because of the significant growth of population lives in the country (CAFRI, 2015). According to the Forest Survey of India report present area in the country under forest and tree cover was 79 million hectares, which is around 24.40 percent of the total geographical area of the country. According to forest policy, 1988 said that country should increase up to 33 percent forest and tree cover area, which is possible through practiced agroforestry at large scale in place of sole agriculture system (FSI, 2017).

\section{Agroforestry Challenges}

Agroforestry systems have one of the best known traditional practices of plantation of different types of multipurpose plants, which give more benefit to local peoples and diversifies the agriculture sole cropping system with the various economically beneficial traditional combination of tree crop cultivation (CAFRI, 2015). There are several difficulties raised to the adoption of agroforestry system in India because of the lack of awareness of the cultivators could not found certified, and registered planting material, seed varieties and most affected challenges when the yield was ready to sell out in market could not find the appropriate price of the yield or marketing challenges. Only about very few like $10 \%$ of planting material is of superior quality and the rest without any guarantee for quality standard (Verma et al. 2017). The study was socio-economic outcome by traditional and commercial agroforestry practices by farmers in the western region of Uttar Pradesh. In the 
traditional agroforestry system, Acacia nilotica, Dalbergia sissoo, Azadirachta indica, and Eucalyptus spp. were dominant tree species whereas Populus deltoids and Eucalyptus spp. were the main species of commercial agroforestry. While traditional agroforestry appears less capable because the main aim of this system is to grow as fulfilling our demand of family consumption or subsistence system and as compared to commercial agroforestry system cultivated to enhance the income by tree products. Still, both agroforestry system plays significant action to the farmers' livelihood and sustainability of improving environment condition (Dwivedi et al. 2010). Traditional agroforestry is a common landuse system in Uttarakhand, which helps various indigenous medicinal plants and traditional crops grown in agroforestry systems to livelihood for local inhabitants. Agroforestry systems in this region are highly developed because of the higher diversity reported from this region, like a total of 68 plant species belonging to 38 families and 63 different genera (Parihaar et al. 2014).

\section{Agroforestry used as biofertilizer}

In agroforestry tree biomass above and below soil surface used as litter which provides different types of fertilizer materials after decomposition of litter of the Ficus benghalensis based agroforestry system commonly found in southern dry agro-climatic region of Karnataka. In a study found that one year of decomposition rotation marginally higher rate of decomposition in sub-surface soil in comparison to surface soil by the Ficus benghalensis based agroforestry litter mass decomposition in the same field. Soil and climatic conditions of the area were found to influence the rate of decomposition by litter (Dhanya et al. 2013). Similarly, in Mandya district, agroforestry litter was studied for decomposition rate constituted around $60 \%$ of the total litter fall of F. benghalensis in the agroforestry system (Dhanya 2011). Microbial biodiversity as the center of the environment facilitates sustainable agroforestry to mankind by giving food, fiber, and non-timber forest products. The major contestants of importance in agroforestry contain symbiotic nitrogen fixers, non-symbiotic nitrogen fixers, phosphate-mobilizing organisms, and disease-preventing endophytic microbes. The composition of microbial variety could be managed based on the diversity of trees and crops measured for the benefit of the agroforestry system (Sridharand Bagyaraj 2018). Decomposition of litter in tropical areas was higher in comparison to temperate areas of the plantation because of the more presence of sunlight required for the decomposition process of litter.

\section{CONCLUSION}

Agroforestry is a system or modern scientifically improved technique for the cultivators to improve our security of socioeconomic conditions and environment cleanliness by the fixed size of the land cultivated all components in the same field. It is clearly shown that traditional and present-day's scientific agroforestry practices fundamentally have several positive assets for the gaining profit of increased biodiversity, which helps environment reformation and economic return of output for the growers across the world. Agricultural crops, woody perennials (tree crops/ forest trees), and animals at the same unit of land at the same time of management are the component and techniques of agroforestry. The present review study presented basic information about the different potential and competence of agroforestry systems to generate sustainable production of income as well as environmental. The maximum species diversity, multi-storied composition, and develops native plants to conserve the environment and richness of diversity. On the other hand, it is significant to message that the impacts of agroforestry are reliant on diverse aspects at different geographical on the different amount for agroforestry systems. It is suggested that equations from all regions should be applied where possible in order to maximize leguminous tree plantation in agricultural lands with appropriate systems to improve socio-economic and environmental benefits to fulfill the demand of the world easily. An understanding of agroforestry practices offers admirable opportunities for finding solutions to the problems of self-reliance and supply of basic needs of the world. The recommendations are that awareness policy, proper management techniques, fulfill suitable planting materials should be continuously advocated the farmers.

\section{REFERENCES}

Abbas, F., Hammad, H.M., Fahad, S., Cerda, A., Rizwan, M., Farhad, W., Ehsan, S. and Bakhat, H.F. 2017. Agroforestry: a sustainable environmental practice for 
carbon sequestration under the climate change scenarios: a review. Environ. Sci. Pollut. Res., 24: 11177-11191.

Aldeen, H.S., Majid, N.M., Azani, A.M., Ghani, A.N.A. and Mohamed, S. 2013. Agroforestry impacts on soil fertility in the Rima'a Valley, Yemen. J. Sustain. For., 32(3): 286-309.

Anderson, S.H., Udawatta, R.P., Seobi, T. and Garrett, H.E. 2015. Soil water content and infiltration in agroforestry buffer strips, Agrofor. Syst., 75: 5-16.

Bangarwa, K.S. and Sirohi, C. 2018. Potentials of poplar and eucalyptus in Indian agroforestry for revolutionary enhancement of farm productivity. Agrofor. J., pp. 335-357.

Basu, J.P. 2014.Agroforestry, climate change mitigation and livelihood security in India. N Z J. For Sci., 44(1): S11.

Benavides, R., Douglas, G.B. and Osoro, K. 2013. Silvopastoralism in New Zealand: review of effects of evergreen and deciduous trees on pasture dynamics, Agrofor. Syst., 76(2): 327-350.

Benjamin, T.J., Hoover, W.L., Seifert, J.R, Gillespie, A.R. 2019. Defining competition vectors in a temperate alley cropping system in the Midwestern USA: The economic return of ecological knowledge. Agrofor. Syst., 48: 79-93.

Bijalwan, A., Sharma, C.M. and Kediyal, V.K. 2011. Socioeconomic status and livelihood support through traditional agroforestry systems in hill and mountain agro-ecosystems of Garhwal Himalaya. Indian For., 14231431.

Bijalwan, A., Manmohan, J. and Dobriyal, R. 2014. Productivity of wheat as intercrop in Grewia optiva based traditional agroforestry system along altitudinal gradient and aspect in mid hills of Garhwal Himalaya, India. Am. J. Environ. Prot., 2(5): 89-94.

Bose, P. 2015. India's dry lands agroforestry ten year analysis of gender and social diversity, tenure and climate variability. Int. For. Rev., 17(4): 85-98.

Buchman, N. 2010. Agroforestry for carbon sequestration to improve small farmer's livelihoods. North-South Centre Research for development.

CAFRI Vision 2015. Central Agroforestry Research Institute, Jhansi, India, 2015.

CFA, Commonwealth Forests 2010: An overview of the forests and forestry sectors of the countries of the commonwealth, commonwealth forestry association, Shropshire, UK, 2010.

Chakraborty, M., Haider, M.Z. and Rahaman, M.M. 2015. Socio-economic impact of cropland agroforestry: evidence from Jessore district of Bangladesh. Int. J. Res. Agric. For., 2(1): 11-20.

Dagar, J.C., Singh, A.K., Arunachalam, A. 2014. Agroforestry systems in India: livelihood security and ecosystem services, pp. 1662-1669.

Dasgupta, S., Todaria, N.P. and Singh, V.P. 2016. Agroforestry mapping and characterization in four districts of Garhwal Himalaya. Energ. Ecol. Environ., 1(2): 86-97.

Deb, S., Deb, D., Sarkar, A. and Majumdar, K. 2014. Community structure, biodiversity value and management practices of traditional agroforestry systems in Tripura, North East India. J. Biodivers. Manag. For., 3(3): 1-6.

Dev, I., Ram, A., Ahlawat, S.P., Palsaniya, D.R., Singh, R., Dhyani, S.K., Kumar, N., Tewari, R. K., Singh, M., Babanna, S.K., Newaj, R., Dwivedi, R.P., Kumar, R.V., Yadav, R.S., Chand, L., Kumar, K. and Prasad, P. 2020. Bamboo based agroforestry system (Dendrocalamus strictus + sesame-chickpea) for enhancing productivity in semi-arid tropics of central India. Agrofor. Syst., 94: 1725-1739.

Devi, N.L. and Das, A.K. 2010. Plant species diversity in the traditional home gardens of Meitei community: A case study from Barak Valley, Assam. J. Trop. Agric., 48: 40-43.

Dhanya, B., Viswanath, S., Purushothaman, S. and Suneeta, B. 2010. Ficus trees as components of rainfed agrarian systems in Mandya district of Karnataka. My. Forest., 46(2): 161-165.

Dhanya, B. 2011. Integrated study of a Ficus based traditional agroforestry system in Mandya district, Karnataka [Ph.D. thesis], Forest Research Institute Deemed University, Dehradun, India.

Dhanya, B., Viswanath, S., and Purushothaman, S. 2013. Crop yield reduction in ficus agroforestry systems of Karnataka, southern India: perceptions and realities. Agroecol. Sustain. Food Syst., 37(6): 727-735.

Dhanya, B., Viswanath, S. and Purushothaman. S. 2013. Decomposition and nutrient release dynamics of Ficus benghalensis L. litter in traditional agroforestry systems of Karnataka, southern India. Hindawi Publishing Corporation ISRN Forestry, 1-7.

Dhanya, B., Sathish, B.N., Viswanath, S. and Purushothaman, S. 2014. Ecosystem services of native trees: experiences from two traditional agroforestry systems in Karnataka, Southern India. Int. J. Biodivers Sci. Ecosyst. Serv. Manag., 10(2): 101-111.

Dhyani, S.K. 2014. National Agroforestry Policy 2014 and the need for area estimation under agroforestry. Curr. Sci., 107(1): 9-10.

Dhyani, S.K., Ram, A. and Dev, I. 2016. Potential of agroforestry systems in carbon sequestration in India. Indian J. Agric. Sci., 86(9): 1103-1112.

Dhyani S.K., Handa A.K., Uma. 2017. Area under agroforestry in India: An assessment for present status and future perspective. Indian J. Agrofor., 15(1): 1-11.

Dwivedi, R.P., Kareemulla, K., Singh, R., Rizvi, R.H. and Chauhan, J. 2010. Socio-economic analysis of agroforestry systems in western Uttar Pradesh. Indian Res. J. Ext. Edu., 7(2\&3): 18-22.

Erakhrumen, A.A., Ogunsanwo, O.Y. and Ajewole, O.I. 2010. Assessment of some other traditional uses of accepted agroforestry fuelwood species in Akinyele and Ido local government areas, Oyo State, Nigeria. Int. J. Soc. For., 3(1): 47-65.

Erakhrumen, A.A., 2012. Influence of specific gravity on wood species selection for agroforestry in some local 
government Areas of Oyo State, Nigeria. African J. Agric. Res., 3(2): 134-139.

Fanish, S.A. and Priya, R.S. 2013. Review on benefits of agro forestry system. Int. J. Educ. Res., 1(1): 1-12.

FSI. 2013. Forest Survey of India India. State of forest report. FSI, Ministry of Environment and Dehradun, India.

FSI. 2017. India State of Forest Report. Ministry of Environment and Forests, Dehradun, India.

Franco, D., Franco, I., Mannino, and G. Zanetto. 2013. The impact of agroforestry networks on scenic beauty estimation the role of a landscape ecological network on a socio-cultural process. Landscape and Urban Plan, 62(3): 119-138.

Gaira, K.S., Rawal, R.S. and Singh, K.K. 2016. Variation in pollinator density and impacts of large cardamom (Amomum subulatum) crop yield in Sikkim, Himalaya, India. J. Asia-Pac. Biodivers., 9: 17-21.

Gupta, N., Kukal, S.S., Bawa, S.S. and Dhaliwal, G.S. 2013. Soil organic carbon and aggregation under poplar based agroforestry system in relation to tree age and soil type. Agrofor. Syst., 76: 27-35.

Horst, G. and Hovorka, A.J. 2019. Fuelwood: the other renewable energy source for Africa? Biomass Bioenerg., 33(11): 1605-1616.

Jaba, D., Moitree, T. and Sourabh, D. 2015. Contribution of women in agroforestry practices of West Tripura, NorthEast India, Oct. Jour. Env. Res., 3(4): 343-351.

Jose, S. 2010. Agroforestry for ecosystem services and environmental benefits: an overview. Agrofor. Syst., 76: 1-10.

Jhariya, M.K. and Raj, A. 2014. Human welfare from biodiversity. Agrobios Newsletter, 12(9): 89-91.

Jhariya, M.K., Raj, A., Sahu, K.P. and Paikra, P.R. 2013. Neema tree for solving global problem. Indian J. Appl. Res., 3(10): 66-68.

Kittur, B.H. and Bargali, S.S. 2013. Perspectives of agroforestry: Present and future facts. J. Progress Agric., 4(2): 91-94.

Kumar, B.M. 2010. Carbon sequestration potential of tropical home gardens. Trop. Homegardens, 1: 185-204.

Kumar, P., Thakur, C.L., Rai,P., and Attri,K. 2018. Identification of Existing Agroforestry Systems and Socio-Economic Assessment in Kandaghat Block of Solan District, Himachal Pradesh, India. Int. J. Curr. Microbiol App. Sci., 7(4): 3815-3826.

Leela, G., Dayana, J., Monisha, S., Irudaya, I., Anitha, A., and Rosaline, J.V. 2016. Studies on phytochemical, nutritional analysis and screening of in vitro biological activities of Melia dubia leaf extract. Int. J. Sci. Eng. Res., 7(8): 56-68.

Manna, M.C. Ghosh, P.K. and Acharya, C.L. 2018. Sustainable crop production through management of soil organic carbon in semiarid and tropical India. J. Sustain. Agric., 21(3): 85-114.

McCabe, C. 2013. Agroforestry and smallholder farmers: Climate change adaptation through sustainable land use.
McAdam, M.R. and Mosquera, L. 2019. Agroforestry in Europe current status and future prospects. Springer Science and Business Media B.V., Dordrecht, pp. 21-41.

Moss, B. 2018. Water pollution by agriculture. Philos. Trans. R. Soc. Lond B. Biol. Sci., 363(1491): 659-666.

Mukherjee, A., Banerjee, S., Nanda, M.K. and Sarkar, S. 2015. Microclimate study under agroforestry system and its impact on performance of tea. J. Agrometeorol., 10(1): 99-105.

Murthy, I.K., Gupta, M, Tomar. S., Munsi, M., Tiwari, R., Hegde, G.T. and Ravindranath, N.H. 2013. Carbon sequestration potential of agroforestry systems in India. J. Earth Sci. Clim. Change, 4(1): 1-7.

Nair, P.K.R. 1993. An introduction to Agroforestry. ICRAF, Nairobi, Kenya. Kluwer Academic Publishers, pp. 243.

Nair, P.K.R., Kumar, B.M. and Nair, V.D. 2010. Agroforestry as a strategy for carbon sequestration. J. Plant Nutr. Soil Sci., 172: 10-23.

Nath, L., Ole, S. and Vetaas, R. 2015. Species diversity between farmland and forest in mid-hills of central Himalaya. Biodivers. Conserv., 1: 2047-2061.

NRCAF, 2006. Perspective Plan-Vision 2025, NRCAF, Jhansi, U.P.

NRCAF. 2013. Vision 2050. National Research Centre for Agroforestry, Jhansi.

Ogunsanwo, O.Y. and Erakhrumen, A.A. 2010. Gender influence on firewood sourcing for income generation in selected rural communities of Oyo State, Nigeria. J. Trop. For Resources, 22(1): 76-83.

Padalia, K.,Bargali, S.S.,Bargali, K. and Parihaar, R.S. 2018. Socio-economic analysis based on energy input and output of mixed cropping systems of Bhabhar Region (Shiwalik range of Kumaun Himalaya, India), Curr. Agric. Res. J., 6(2): 123-140.

Pandey, D.N. 2011. Multifunctional agroforestry systems. Curr. Sci., 92(4): 1-8.

Pandey, A.K., Gupta, V.K. and Solanki, K.R. 2012. Productivity of neem-based agroforestry system in semi-arid region of India. Range Manag. Agrofor., 31(2): 144-149.

Parihaar, R.S., Bargali, K. and Bargali, S.S. 2014. Diversity and uses of ethno-medicinal plants associated with traditional agroforestry systems in Kumaun Himalaya. Indian J. Agric. Sci., 84(12): 1470-1476.

Raj, A., Jhariya, M.K. and Pithoura, F. 2014. Need of agroforestry and impact on ecosystem. J. Plant Dev. Sc., 6(4): 577-581.

Raj, A., Jhariya, M.K. and Bargali S.S. 2016. Bund based agroforestry using eucalyptus species: a review. Curr. Agric. Res. J., 4(2): 148-158.

Ramnewaj, Chavan, S.B., Alam, B. and Dhyani, S.K. 2016. Biomass and carbon storage in trees grown under different agroforestry systems in semiarid region of central India. Indian Forester, 142(7): 642-648.

Rao, K.P.C., Verchot, L.V. and Laarman, J. 2017. Adaptation to climate change through sustainable management and 
development of agroforestry systems. An Open Access Journal published by ICRISAT, 4(1): 1-30.

Rawat, V., Lal, S. B., Khare, N. and Umrao, R. 2016. Socioeconomic feasibility of some of the villages of Chamoli district of Garhwal Himalayas. Int. J. For Crop Improv., 7(1): 61-66.

Rockwood, D.L., Naidu,C.V., Carter,D.R., Rahmani,M., Spriggs, T.A., Lin,C., Alker,G. R., Isebrands,J. G.and Segrest,S. A. 2014. Short-rotation woody crops and phytoremediation: Opportunities for agroforestry? Agroforestry System, 61-62(1-3): 51-63.

Rodríguez, R.A, Fernández-Núñez, E., González-Hernández, P., McAdam, J.H. and Mosquera- Losada, M.R. 2011. Agroforestry systems in Europe: productive, ecological and social perspectives. In: Agroforestry in Europe: current status and future prospects. Springer.

Saha, S.K., Nair, P.K.R., Nair, V.D. and Kumar, B.M. 2010. Carbon storage in relation to soil size-fractions under tropical tree-based land-use systems. Plant Soil, 328: 433-446.

Sehgal, R.N., Rathore, A. and Chauhan, S.K. 2010. Divergence studies in selected genotypes of Grewia optiva. Indian J. Agrofor., 5(1\&2): 99-102.

Saravanan, V., Parthiban, K.T., Kumar, P., and Marimuthu, P. 2013. Wood characterization studies on Melia dubia Cav. for pulp and paper industry at different age gradation. Res. J. Recent Sci., 2: 183-188.

Sharma, K.L., Ramachandra, Raju, K, Das, S.K., Prasadrao, B.R.C., Kulkarni, B.S., Srinivas, Kusuma, G.K.J., Madhavi, M. and Gajbhiye, P.N. 2019. Soil fertility and quality assessment under tree-, crop-, and pasture-based land-use systems in a rainfed environment. Commun. Soil Sci. Plant Anal., 40: 9-10,

Sharma, P., Singh, M.K., Tiwari P. and Verma, K. 2017. Agroforestry systems: Opportunities and challenges in India. J. Pharmacog. Phytochem., SP-1: 953-957.

Singh, V.S. and Pandey, D.N. 2011. Multifunctional agroforestry systems in India: Science-based policy options. RSPCB Occasional Paper No 4: 2-35.

Singh, N.R., Jhariya, M.K. and Raj, A. 2013. Tree crop interaction in agroforestry system. Readers Shelf, 10(3): $15-16$.

Singh, A.K., Dhayani, S.K. 2014. Agroforestry policy issues and challenges. In: Agroforestry systems in India: Livelihood security \& ecosystem services (eds.), India. Adv. Agron., pp. 367-372.
Singh, V. and Ramchandra 2019. Study on socio-economic status and characteristics of farmers adopting agroforestry system in Kaushambi district of eastern Uttar Pradesh, India. Int. J. Farm Sci., 9(4): 1-6.

Smith, J. 2010. Agroforestry: Reconciling production with protection of the environment: A Synopsis of Research Literature.

Sridhar, K.R. and Bagyaraj, D.J. 2018. Microbial biodiversity in agroforestry systems. Agrofor. Syst., pp. 645-667.

Subba, M., Pala, N. A., Shukla, G., Pradhan, K. and Chakravarty, S. 2017. Relationship of Socio-Economic Factors with Attributes of Home garden. Agroforestry Systems in Northern Part of West Bengal. J. Tree Sci., 36(2): 76-91.

Sudha, P., Ramprasad, V., Nagendra, M.D.V., Kulkarni, H.D. and Ravindranath, N.H. 2013. Development of an agroforestry carbon sequestration project in Khammam district, India. Mitigat. Adapt. Strat. Climate Change, 12: 1131-1152.

Tassin, J., Rangan, H. and Kull, C.A. 2012. Hybrid improved tree fallows: Harnessing invasive woody legumes for agroforestry. Agrofor. Syst., 84(3): 417-428.

Tiwari, P., Kumar, R., Thakur. L. and Salve, A. 2017. Agroforestry for Sustainable Rural Livelihood: A Review. Int. J. Pure App. Biosci., 5(1): 299-309.

Toppo, P. and Raj, A. 2018. Role of agroforestry in climate change mitigation. J. Pharmacog. Phytochem., 7(2): 241-243.

Tyndall, J. and Colletti, J. 2011. Mitigating swine odor with strategically designed shelterbelt systems: a review. Agrofor. Syst., 69(1): 45-65.

Verma, P., Bijalwan, A., Dobriyal, M.J.R., Swamy, S.L. and Thakur, T.K. 2017. A paradigm shift in agroforestry practices in Uttar Pradesh, Curr. Sci., 112(3): 509-516.

Viswanath, S., Lubina, P.A., Subbanna, S. and Sandhya, M.C. 2018. Traditional agroforestry systems and practices: A review. Adv. Agric. Res. Technol. J., 2(1): 18-29.

World Agro-forestry Centre. 2010. Transforming lives and landscapes, pp. 1-5. 
